Original Research Article

\title{
Analgesic activity of allopurinol and febuxostat in experimental animals
}

\author{
Yajnesh P. Sahu, Sachchidanand Pandey*, Sabita Mohapatra
}

Department of Pharmacology, V.S. S. Institute of Medical Sciences and Research, Burla, Sambalpur, Odisha, India

Received: 20 February 2018

Accepted: 26 February 2018

\section{*Correspondence to:}

Dr. Sachchidanand Pandey, Email: drsnpandey2006@ gmail.com

Copyright: () the author(s), publisher and licensee Medip Academy. This is an openaccess article distributed under the terms of the Creative Commons Attribution NonCommercial License, which permits unrestricted noncommercial use, distribution, and reproduction in any medium, provided the original work is properly cited.

\begin{abstract}
Background: Currently, two classes of analgesics, nonsteroidal antiinflammatory drugs (NSAIDs) and opioid analgesics are used to manage pain in different clinical situations. Chronic uses of these drugs have various adverse effects like gastric ulceration/bleeding, analgesic nephropathy and respiratory depression, physical dependence, addiction, respectively. Xanthine oxidase inhibitors, used for chronic gout, might have a role in alleviation of pain, as per literature survey. Hence, the present study was carried out to evaluate the potential analgesic activity of allopurinol and febuxostat in different experimental models.

Methods: The analgesic activity of allopurinol and febuxostat was assessed by employing two different experimental pain models-tail flick latency model in rats for central analgesia and acetic acid induced writhing model in mice for peripheral analgesia and was compared with tramadol and aspirin.

Results: Allopurinol and febuxostat produced significant central and peripheral analgesic effects as is evident from increase in reaction time in tail flick test and inhibition in number of writhes in acetic acid induced writhing test.

Conclusions: The results of the present study demonstrate marked analgesic effect of allopurinol and febuxostat.
\end{abstract}

Keywords: Acetic acid induced writhing, Tail flick latency, Xanthine oxidase inhibitor

\section{INTRODUCTION}

Pain is the most common ailment for which patients seek medical advice. Chronic pain is very distressing where appropriate pain assessments together with adequate pain management are the standard of care in this situation.

Analgesics are drugs which decrease pain sensation by increasing the nociceptive threshold to external stimuli without altering consciousness. ${ }^{1}$ Two classes of analgesics are currently available, the nonsteroidal anti-inflammatory drugs (NSAIDs) and Opioid analgesics, but they have significant side-effect like gastric ulceration/bleeding, analgesic nephropathy, increased risk of myocardial infarction, stroke and respiratory depression, constipation, physical dependence, addiction, respectively.
Gout is a chronic, painful, metabolic inflammatory disease, caused due to increased serum uric acid levels in which NSAIDs and corticosteroid are used for acute gout, whereas urate-lowering drugs like Allopurinol, Febuxostat (by inhibition of enzyme Xanthine Oxidase (XO), both synthesis inhibitors) and Probenecid (uricosuric drug) are used for chronic gout. ${ }^{2-4}$ Conventionally they do not have any role in reducing pain of acute gout.

The enzyme Xanthine Oxidase (XO) is also responsible for catalyzing other biochemical reactions in the body, like conversion of NADH to NAD where reactive oxygen species (ROS) is released as a by-product, which have been implicated in producing pain and inflammation. ${ }^{5}$ Also, XO Inhibitors, by increasing hypoxanthine levels, allow its increased conversion to inosine and inosine monophosphate which gets converted to adenosine 
(through purine salvage pathway). Adenosine is found to have a role in the modulation of pain. ${ }^{6}$ Recently, chronic inhibition of XO-generated ROS by Allopurinol has been suggested to inhibit symptoms of inflammation, painful diabetic neuropathy in rats and to produce acute antinociceptive activity against a variety of noxious stimuli in mice. $^{7,8}$ Febuxostat is a newer orally administered nonpurine XO inhibitor that has been recently approved for the treatment of chronic hyperuricemia in patients with gout. ${ }^{9}$ Three randomized controlled clinical trials comparing Febuxostat with Allopurinol showed that $40 \mathrm{mg} /$ day Febuxostat lowered serum uric acid to similar levels as $300 \mathrm{mg} /$ day of Allopurinol. ${ }^{10}$ It also may possess analgesic activity like Allopurinol through the aforementioned mechanisms. These reports lead to the possibility of XO Inhibitors like Allopurinol and Febuxostat to possess analgesic activity of which there is paucity of data. Hence, this study attempts to explore the analgesic activity of Allopurinol and Febuxostat in selected animal models.

\section{METHODS}

The study was conducted in the P.G. Department of Pharmacology, V. S. S. Medical College, Burla after obtaining due approval from Institutional Animal Ethics Committee, VIMSAR, Burla. All the animals were handled carefully as per the CPCSEA guidelines.

\section{Experimental animals}

Adult healthy Wistar albino rats weighing between 150$200 \mathrm{gms}$ and Swiss albino mice weighing between 15$20 \mathrm{gms}$ were selected for the study. They were kept in polypropylene cages in 12:12 hours light:dark cycle, provided with standard laboratory diet and had water ad libitum. Food was withdrawn 12 hours before and during experimental hours. ${ }^{11}$

\section{Tail Flick Latency (TFL) test}

\section{Animals}

48 Wistar albino rats were taken for this study.

\section{Drugs and reagents}

Tramadol (ACME Laboratories Ltd)- Standard drug, Allopurinol (Glaxo-Smith Kline Pharma.), Febuxostat (Zydus Cadila Pharma Ltd.) and 0.5\% Carboxy Methyl Cellulose (CMC) (E-Merck India) were used for the study.

The rats were divided into 8 groups of 6 animals in each and were administered with test and control drugs orally through intragastric tube. Group I was used as control receiving $0.5 \% \mathrm{CMC}$. Group II was given standard drug Tramadol 10mg/kg. Group III, IV and V received Allopurinol in doses of 50, 100 and $200 \mathrm{mg} / \mathrm{kg}$ respectively. Group VI, VII and VIII received Febuxostat in doses of 5, 10 and $20 \mathrm{mg} / \mathrm{kg}$ respectively. Pre-drug and post-drug TFL was assessed at $0 \mathrm{hr}, 0.5 \mathrm{hr}, 1 \mathrm{hr}, 2 \mathrm{hr}$ and $3 \mathrm{hr}$.

Each rat was placed in the rat holder and the base of the protruding out was placed on the heated nichrome wire $(6$ Amp) of Analgesiometer (INCO, India). The time taken from the application of heat to the flicking of the tail (TFL) was recorded. The cut-off time was fixed at $10 \mathrm{sec}$ to avoid tissue damage. The rats which showed a TFL of 5 to 6 seconds at baseline were included for the study.

\section{Statistical analysis}

One-way ANOVA was used to test statistical significance of the post-drug values from the pre-drug values. The percentage increase / decrease in reaction time (as index of analgesia) at each time interval was calculated.

$\%$ Analgesia (Maximum Possible Effect=MPE) $=($ TL-BL /ML-BL) $\times 100$

Where $\mathrm{ML}=$ Maximum Latency $(10 \mathrm{sec}), \mathrm{TL}=$ Test Latency, BL $=$ Basal Latency

\section{Acetic acid induced writhing test}

Animals

48 Swiss albino mice were taken for this study.

Drugs and reagents

Aspirin (ACME Laboratories Ltd)-Standard drug and 0.6\% Acetic Acid (E-Merck India) were used.

\section{Procedure}

Mice were intragastrically administered with test and control drugs in a similar fashion as the TFL test, $30 \mathrm{~min}$ before Intraperitoneal injection of acetic acid $(0.6 \%)$. Then mice were placed in separate bell shaped transparent glass jars and numbers of abdominal constrictions (writhes) were counted over a period of 10 minutes commencing 10 min after injection of acetic acid. The difference in number of writhes in test group was compared with standard treated and control treated groups.

\section{Statistical analysis}

One-way ANOVA was used to test statistical significance of the test drug values from the control values. The percentage increase/decrease in number of writhing (as index of analgesia) was calculated. The Percentage Inhibition was calculated by formula:

$\%$ Inhibition $=[(\mathrm{Wc}-\mathrm{Wt}) \times 100] / \mathrm{Wc}$

Where $\mathrm{Wc}=$ No. of writhes in control group, $\mathrm{Wt}=$ No of writhes in test group. 


\section{RESULTS}

\section{Tail flick latency test}

In this test, three doses each of Allopurinol and Febuxostat were compared with the standard drug Tramadol and Control drug $(0.5 \% \mathrm{CMC})$. The results of analgesic activity of drugs by Tail Flick Test are shown in the Table 1.

The Basal latency (predrug TFL) in all groups was comparable. Allopurinol 100 and $200 \mathrm{mg} / \mathrm{kg}$ and febuxostat $20 \mathrm{mg} / \mathrm{kg}$ showed significant increase in TFL, in comparison with predrug TFL value, from 30 min to 3 hour of observation. Tramadol $10 \mathrm{mg} / \mathrm{kg}$ showed similar effect. However, the effect shown by the test drugs i.e. Allopurinol and Febuxostat was significantly lower than tramadol $10 \mathrm{mg} / \mathrm{kg}$. The effect shown with allopurinol $200 \mathrm{mg} / \mathrm{kg}$ was significantly higher than allopurinol $100 \mathrm{mg} / \mathrm{kg}$ depicting a dose dependent response. The effect seen with febuxostat $20 \mathrm{mg} / \mathrm{kg}$ dose was significantly greater than allopurinol $100 \mathrm{mg} / \mathrm{kg}$ but lower than allopurinol $200 \mathrm{mg} / \mathrm{kg}$. Allopurinol 50mg/kg, febuxostat $5 \mathrm{mg} / \mathrm{kg}$ and febuxostat $10 \mathrm{mg} / \mathrm{kg}$ did not show significant increase in TFL. Percentage Analgesia with Allopurinol and Febuxostat in TFL Test in Rats is shown in Table 2.

Table 1: Effect of allopurinol and febuxostat on tail flick latency of rats.

\begin{tabular}{|c|c|c|c|c|c|c|}
\hline \multirow{2}{*}{ Group } & \multirow{2}{*}{$\begin{array}{l}\text { Drug / dose } \\
\text { (mg/kg) }\end{array}$} & \multicolumn{5}{|c|}{ Mean TFL (in sec \pm SEM) } \\
\hline & & Basal & 30min & $1 \mathrm{hr}$ & $2 \mathrm{hr}$ & $3 \mathrm{hr}$ \\
\hline I & CMC $(0.5 \%)$ & $3.41 \pm 0.08$ & $4 \pm 0.08$ & $3.12 \pm 0.08$ & $3.69 \pm 0.04$ & $3.53 \pm 0.06$ \\
\hline II & Tramadol 10 & $3.65 \pm 0.06$ & 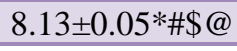 & $8.3 \pm 0.05 * \# \$ @$ & $8.51 \pm 0.05 * \# \$ @$ & $8.38 \pm 0.05 * \# \$ @$ \\
\hline III & Allopurinol 50 & $3.19 \pm 0.02$ & $3.10 \pm 0.02$ & $3.25 \pm 0.06$ & $3.27 \pm 0.04$ & $3.21 \pm 0.06$ \\
\hline IV & Allopurinol 100 & $3.56 \pm 0.10$ & $6.05 \pm 0.05 *$ & $6.20 \pm 0.07 *$ & $6.44 \pm 0.05 *$ & $6.28 \pm 0.04 *$ \\
\hline $\mathrm{V}$ & Allopurinol 200 & $3.85 \pm 0.04$ & $7.71 \pm 0.04 * \# \$$ & $7.76 \pm 0.03 * \# \$$ & $7.84 \pm 0.05^{* \# \$}$ & $7.86 \pm 0.03 * \# \$$ \\
\hline VI & Febuxostat 5 & $3.57 \pm 0.09$ & $3.60 \pm 0.04$ & $3.39 \pm 0.08$ & $3.38 \pm 0.08$ & $3.37 \pm 0.09$ \\
\hline VII & Febuxostat 10 & $3.59 \pm 0.09$ & $3.84 \pm 0.12$ & $3.22 \pm 0.03$ & $3.22 \pm 0.02$ & $3.11 \pm 0.00$ \\
\hline VIII & Febuxostat 20 & $3.5 \pm 0.07$ & $6.47 \pm 0.06^{* \#}$ & $6.91 \pm 0.04 * \#$ & $7.220 .04 * \#$ & $7.01 \pm 0.05$ *\# \\
\hline
\end{tabular}

Data were analyzed by ANOVA followed by Post hoc - Tukey Test. Each value is expressed as Mean \pm SEM. $n=6 . *$ is $p$ value $<0.001$ compared to control, \# is p value $<0.05$ compared to Allopurinol 100, @ is p value $<0.05$ compared to Allopurinol 200, $\$$ is $p$ value $<0.05$ compared to Febuxostat 20.

Table 2: Percentage analgesia with allopurinol and febuxostat in TFL test in rats.

\begin{tabular}{|lllll|}
\hline \multirow{2}{*}{$\begin{array}{l}\text { Drug and dose } \\
\text { (mg/kg) }\end{array}$} & \multicolumn{4}{l}{$\begin{array}{l}\text { Percentage maximum possible } \\
\text { effect (\% Analgesia) in Rats }\end{array}$} \\
\hline Tramadol - 10 & 30min & 1hr & 2hr & 3hr \\
\hline Allopurinol - 100 & 38.66 & 73.22 & 76.53 & 74.48 \\
\hline Allopurinol - 200 & 62.76 & 63.57 & 64.87 & 65.20 \\
\hline Febuxostat- 20 & 45.69 & 52.46 & 57.23 & 54 \\
\hline
\end{tabular}

\section{Acetic acid induced writhing test}

The analgesic effect of Allopurinol and Febuxostat was evaluated with the help of Acetic Acid Induced Writhing Test. The number of writhes in mice was recorded for both the drugs and was compared with that of control $(0.5 \%$ CMC) and standard (Aspirin). The results of analgesic activity by Acetic Acid Induced Writhing Test are shown in the Table 3.

On comparison with control, allopurinol 100 and $200 \mathrm{mg} / \mathrm{kg}$ and febuxostat $20 \mathrm{mg} / \mathrm{kg}$ dose showed significant reduction in number of writhes in mice. Aspirin showed similar effect. However, the effect shown by the test drugs i.e. allopurinol and febuxostat was significantly lower than aspirin $100 \mathrm{mg} / \mathrm{kg}$.
Table 3: Effect of allopurinol and febuxostat on acetic acid induced writhing response in mice.

\begin{tabular}{|c|c|c|c|}
\hline Group & $\begin{array}{l}\text { Drug and } \\
\text { dose } \\
(\mathrm{mg} / \mathrm{kg})\end{array}$ & $\begin{array}{l}\text { No of writhes } \\
\text { Mean } \pm \text { SEM }\end{array}$ & $\begin{array}{l}\% \\
\text { Protection }\end{array}$ \\
\hline I & $\begin{array}{l}\text { Control } \\
(0.5 \% \text { CMC })\end{array}$ & $28.83 \pm 1.01$ & - \\
\hline II & Aspirin 100 & $6.83 \pm 0.30 * \# @ \$$ & 76.3 \\
\hline III & $\begin{array}{l}\text { Allopurinol } \\
50\end{array}$ & $28.67 \pm 0.71$ & 0.5 \\
\hline IV & $\begin{array}{l}\text { Allopurinol } \\
100\end{array}$ & $17.33 \pm 0.33 *$ & 39.88 \\
\hline V & $\begin{array}{l}\text { Allopurinol } \\
200\end{array}$ & $10.83 \pm 0.47 * \# \$$ & 62.43 \\
\hline VI & Febuxostat 5 & $28.50 \pm 0.42$ & 1.14 \\
\hline VII & $\begin{array}{l}\text { Febuxostat } \\
10\end{array}$ & $25.67 \pm 1.43$ & 10.96 \\
\hline VIII & $\begin{array}{l}\text { Febuxostat } \\
20\end{array}$ & $19.50 \pm 0.50 *$ & 32.36 \\
\hline
\end{tabular}

Data were analyzed by ANOVA followed by Post hoc - Tukey Test. Each value is expressed as Mean \pm SEM. $n=6$. * is p value $<0.001$ compared to control, \# is $\mathrm{p}$ value $<0.05$ compared to Allopurinol-100, @ is p value <0.05 compared to Allopurinol$200, \$$ is p value $<0.05$ compared to Febuxostat 20.

The effect shown with allopurinol $200 \mathrm{mg} / \mathrm{kg}$ was significantly higher than allopurinol $100 \mathrm{mg} / \mathrm{kg}$ depicting a 
dose dependent response. Allopurinol $50 \mathrm{mg} / \mathrm{kg}$, febuxostat $5 \mathrm{mg} / \mathrm{kg}$ and febuxostat $10 \mathrm{mg} / \mathrm{kg}$ did not show any change in number of writhes in mice as compared to control. Percentage Analgesia of Allopurinol and Febuxostat in Acetic Induced Writhing Method is shown in Figure 1.

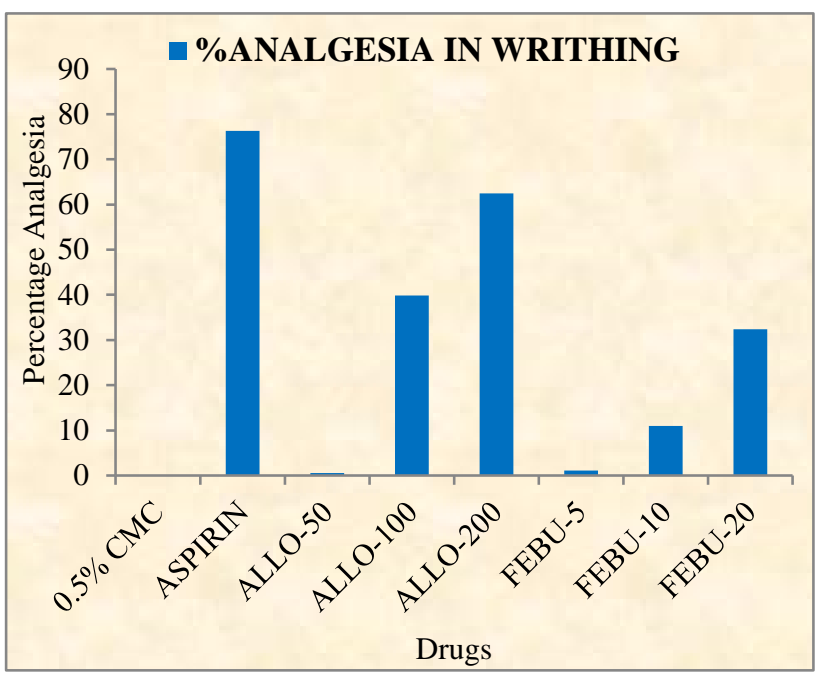

Figure 1: Bar diagram showing percentage analgesia of allopurinol and febuxostat in acetic induced writhing method.

\section{DISCUSSION}

There is paucity of data available evaluating the analgesic activity of Allopurinol and Febuxostat. These drugs are already in use since long for the management of chronic painful inflammatory disease like Gout for decreasing uric acid levels. Their additional analgesic activity, if ascertained, can significantly be useful in the treatment of chronic painful conditions as XO Inhibitors are known to be safer than the available NSAIDs and Opioids in terms of having negligible adverse effects.

Allopurinol and febuxostat showed analgesic activity against both experimental models of pain. In TFL test, the $100 \mathrm{mg} / \mathrm{kg}$ and $200 \mathrm{mg} / \mathrm{kg}$ dose of allopurinol and $20 \mathrm{mg} / \mathrm{kg}$ febuxostat showed significant analgesic effect from $30 \mathrm{~min}$ to 3 hours of observation time. The peak effect was observed at 2 hours with all the drugs.

However, these effects were significantly less than the standard dose $(10 \mathrm{mg} / \mathrm{kg})$ of tramadol. Allopurinol produced a dose dependent analgesic effect. Percentage analgesia or MPE was found to be 44.72 and 65.2 for allopurinol $100 \mathrm{mg} / \mathrm{kg}$ and $200 \mathrm{mg} / \mathrm{kg}$ dose respectively during their peak effect while that of tramadol was 76.53. Percentage analgesia or MPE of $20 \mathrm{mg} / \mathrm{kg}$ febuxostat was found to be 57.23 which was significantly greater than $100 \mathrm{mg} / \mathrm{kg}$ of allopurinol whereas significantly lower than $200 \mathrm{mg} / \mathrm{kg}$ allopurinol. In this test $50 \mathrm{mg} / \mathrm{kg}$ allopurinol, 5 and $10 \mathrm{mg} / \mathrm{kg}$ febuxostat did not show any analgesic activity. These effects corroborate with the findings of other workers. ${ }^{12,13}$ However febuxostat was not included in their study.

In acetic acid induced writhing test in mice, the two high doses of allopurinol i.e. 100 and $200 \mathrm{mg} / \mathrm{kg}$ and highest dose of Febuxostat i.e. $20 \mathrm{mg} / \mathrm{kg}$ exhibited significant analgesic effect. The percentage analgesia seen with allopurinol 100 and $200 \mathrm{mg} / \mathrm{kg}$ and febuxostat $20 \mathrm{mg} / \mathrm{kg}$ were $39.88,62.43$ and 32.36 respectively which were significantly lower than that of aspirin (76.3). Here also dose dependent analgesic effect of allopurinol was observed. In this test too, $50 \mathrm{mg} / \mathrm{kg}$ Allopurinol, 5 and $10 \mathrm{mg} / \mathrm{kg}$ Febuxostat did not show any analgesic activity. Similar effects were observed in Acetic acid induced writhing method by some other workers. ${ }^{12-14}$

Allopurinol and febuxostat possess significant analgesic activity. These drugs may be useful in chronic painful conditions like inflammatory arthritis, sickle cell disease, diabetic neuropathy, fibromyalgia and cancer.

\section{ACKNOWLEDGEMENTS}

Authors would like to thank Head of the Department of Pharmacology and other staffs of V. S. S. Institute of Medical Sciences and Research, Burla for their support in conducting the study.

Funding: No funding sources Conflict of interest: None declared

Ethical approval: The study was approved by the Institutional Ethics Committee, VIMSAR, Burla

\section{REFERENCES}

1. Rathmell JP, Fields HL. Pain: Pathophysiology and Management, Harrison's Principals of Internal Medicine. 18th ed, Vol. 1. New Delhi: McGrew Hill Publication; 2012:93101.

2. Schumacher HR, Chen LX. Gout and other crystal associated arthropathies. In: Fauci AS, Jameson JL, Hauser SL, Kasper DL, Longo DL, Loscalzo J, editors. Harrison's Principles of Internal Medicine. 18th ed. New Delhi: McGrawHill; 2012:283742.

3. Grosser T, Smyth E, FitzGerald GA. Antiinflammatory, antipyretic, and analgesic agents; pharmacotherapy of gout. Goodman and Gilman's the pharmacological basis of therapeutics. 2011;12:9591004.

4. Pacher P, Nivorozhkin A, Szabó C. Therapeutic effects of xanthine oxidase inhibitors: renaissance half a century after the discovery of allopurinol. Pharmacological reviews. 2006;58(1):87-114.

5. McCord JM, Fridovich I. Superoxide dismutase. An enzymic function for erythrocuprein (hemocuprein). J Biol Chem. 1969;244(22):6049-55.

6. Sawynok J, Liu XJ. Adenosine in the spinal cord and periphery: release and regulation of pain. Progress Neurobiol. 2003;69(5):313-40. 
7. Inkster ME, Cotter MA, Cameron NE. Treatment with xanthine oxidase inhibitor, allopurinol, improves nerve and vascular function in diabetic rats. Euro $\mathrm{J}$ Pharmacol. 2007;561:63-71.

8. Schmidt AP, Bohmer AE, Antunes C, Schallenberger C, Porincula LO, Elisabetsky E. Antinociceptive properties of the xanthine oxidase inhibitor allopurinol in mice: role of adenosine A1 receptors. $\mathrm{Br} \mathrm{J}$ Pharmacol. 2008;156:161-70.

9. Vogel H. Drug Discovery and Evaluation of Pharmacological Assay. 2nd ed. Berlin: Springer. 2002:3912.

10. Gilman AG. Goodman and Gilman's the pharmacological basis of therapeutics. 12th ed. 1998.

11. Institute of Laboratory Animal Resources (US). Committee on Care, Use of Laboratory Animals, Norman Grossblatt. Guide for the Care and Use of Laboratory Animals. National Academies; 1978.

12. Pise HN, Padwal SL, Motghare VM, Deshmukh VS, Jaykare SC, Jadhav SS. Investigation of analgesic activity of xanthine oxidase inhibitor allopurinol: an experimental study. Inter $\mathbf{J}$ Pharm Pharmaceu Sci. 2015;7(3).

13. Schmidt AP, Böhmer AE, Antunes C, Schallenberger C, Porciúncula LO, Elisabetsky E, et al. Analgesic properties of xanthine oxidase inhibitor allopurinol in mice: role of Aladenosine receptor. Br J Pharmacol. 2009;156(1):163-72.

14. Shankpal PD, Hotwani JH, Chitnis KA, Tadke DS, Kokani VR. Evaluation of analgesic activity of allopurinol and febuxostat in experimental analgesic models in mice. Ind J Pain. 2015;29(2):106.

Cite this article as: Sahu YP, Pandey S, Mohapatra $\mathrm{S}$. Analgesic activity of allopurinol and febuxostat in experimental animals. Int J Basic Clin Pharmacol 2018;7:603-7. 